\title{
Fusulines of the Hoyo Oscuro section, Ándara Massif of Picos de Europa (Cantabrian Zone, N Spain). New constraints about the onset of the Variscan deformation
}

\author{
Oscar MERINO-TOMÉ*, Elisa VILLA, Luis Pedro FERNÁNDEZ \& Juan R. BAHAMONDE
}

Departamento de Geología, Universidad de Oviedo, c/ Jesús Arias de Velasco, s/n, 33005 Oviedo, Spain; omerino@geol.uniovi.es; evilla@uniovi.es; lpedro@geol.uniovi.es; jrbaham@geol.uniovi.es

* Corresponding author

Merino-Tomé, O., Villa, E., Fernández, L.P. \& Bahamonde, J.R. 2020. Fusulines of the Hoyo Oscuro section, Ándara Massif of Picos de Europa (Cantabrian Zone, N Spain). New constraints about the onset of the Variscan deformation. [Fusulinas de la sección del Hoyo Oscuro, Macizo de Ándara, Picos de Europa (Zona Cantábrica, N España). Nuevas precisiones sobre el inicio de la deformación Varisca]. Spanish Journal of Palaeontology, 35 (1), 107-124.

Manuscript received 26 June 2019

Manuscript accepted 8 November 2019 https://doi.org/10.7203/sjp.35.1.17238

(C) Sociedad Española de Paleontología ISSN 2255-0550

\begin{abstract}
The Hoyo Oscuro section (Ándara Massif, southeastern part of Picos de Europa) is a comparatively small exposure of Pennsylvanian syntectonic deposits that shown angular unconformity on the fairly extensive pre-tectonic carbonate platform strata of Pennsylvanian age accumulated in the distalmost realms of the Variscan foreland basin of the Cantabrian Zone. Fusuline-bearing strata from this section yielded species belonging to the genera Pseudostaffella, Ozawainella, Fusulinella, Protriticites, Pseudotriticites, Fusulina and Quasifusulinoides; one of these forms, Protriticites schulzei Villa, is described as a new species from the Cantabrian Mountains. Fusuline assemblages allow us to correlate the Hoyo Oscuro strata with the syntectonic successions of the northern part of Picos de Europa (Gamonedo area) and with specific intervals of the Picos de Europa Formation that, according to currently accepted models, were pre-tectonic. The age data obtained for the oldest syntectonic deposits of the studied section are of key importance, since they constitute a new anchor point
\end{abstract}

\section{RESUMEN}

La sección de Hoyo Oscuro (Macizo de Ándara, Picos de Europa) aparece expuesta en un afloramiento relativamente reducido de brechas y turbiditas calcáreas y de depósitos de rampa carbonatada que se disponen mediante una discordancia angular sobre las calizas de plataforma de la Formación Picos de Europa. La sección, en la que se han podido separar cuatro secuencias estratigráficas distintas, ha proporcionado abundantes fusulinas de los géneros Pseudostaffella, Ozawainella, Fusulinella, Protriticites, Pseudotriticites, Fusulina y Quasifusulinoides. Una de las especies, Protriticites schulzei Villa sp. nov., se describe como nueva forma del Pensilvánico superior de la Cordillera Cantábrica. Las asociaciones de fusulinas propias de cada intervalo permiten correlacionar las secuencias identificadas en la sección de Hoyo Oscuro con las sucesiones sinorogénicas (sintectónicas) de la parte septentrional de los Picos de Europa (área de Gamonedo), así como con niveles concretos de la sucesiones de plataforma carbonatada de la Formación Picos de Europa previamente estudiadas en el mismo Macizo de 
confirming the onset of the Variscan Orogeny in this part of the Cantabrian Zone.

Keywords: Fusulines, Carboniferous (Pennsylvanian), Cantabrian Zone, Variscan Orogeny, Picos de Europa.
Ándara, consideradas como pretectónicas. La edad de la secuencia sinorogénica más antigua (Secuencia 1) expuesta en Hoyo Oscuro confirma el momento (final del Moscoviense) en el que se inició la actividad orogénica varisca en esta parte de la Zona Cantábrica.

Palabras clave: Fusulinas, Carbonífero (Pensilvánico), Zona Cantábrica, Orogenia Varisca, Picos de Europa.

\section{INTRODUCTION}

The Picos de Europa mountains (NW Spain) expose the largest outcrop of Carboniferous limestones of Western Europe, representing a thick imbricated thrust-nappe stack originated in the NW of the foreland fold-and-thrust belt of the Variscan Orogen (Julivert, 1978; Pérez-Estaún et al., 1988; Alonso et al., 2009; Merino-Tomé et al., 2009a) (Fig. 1). Both the Mississippian and the Pennsylvanian successions of this area consist almost exclusively of limestone strata that, in the case of the latter, accumulated in an extensive microbial-dominated carbonate platform developed in the distalmost realms of the Variscan foreland basin (Bahamonde et al., 2000, 2000, 2007). During late Pennsylvanian times, the area was affected by tectonic thrusting as Variscan deformation advanced towards the foreland, and a number of basins replaced the once extensive (pre-tectonic) carbonate platform (MerinoTomé et al., 2009a). The syntectonic basin-fill strata, representing the wedge-top depozone of DeCelles \& Giles (1996), mainly comprise marine siliciclastic successions including abundant detrital calcareous sediments and in situ carbonate deposits recording the local development of thrust-top carbonate ramps (Merino-Tomé et al., 2006, 2007, 2009a, 2009b; Villa et al., 2015).

The timing of tectonic deformation in the Picos de Europa area is based mostly on accurate dating of fusuline assemblages recovered from both the youngest pre-tectonic strata of the underlying Pennsylvanian carbonate platform and the syntectonic deposits (e.g. van Ginkel \& Villa, 1991, 1999; Villa, 1995; Martínez-García \& Villa, 1999; Villa \& van Ginkel, 2000; Merino-Tomé et al., 2006; Cózar et al., 2007; Villa et al., 2015, among others). This biostratigraphical work is of key importance for better understanding the last phases of the Variscan Orogeny in the Cantabrian Zone, including the closure of the IberoArmorican Arc.

An upper Myachkovian age was confirmed for the oldest syntectonic successions cropping out in two areas: a) the thrust nappes of the rear part of the Picos de Europa imbricate system (Gamonedo-Cabrales-Panes sector), where autochthonous limestone strata alternate with thick deltaic, fan-deltaic and turbiditic packages (Villa, 1995;
Merino-Tomé et al., 2006, 2009a); and b) the so-called Pirué beds, which are exposed in the vicinity of Sotres (Martínez García \& Villa, 1999) (Fig. 1b). In contrast, in the central and frontal areas of the Picos de Europa imbricate system, the oldest unequivocal syntectonic limestone strata discovered corresponded to the lower Kasimovian autochthonous limestones of the Las Llacerias Formation, which are late Krevyakinian to Khamovnikian in age (Villa \& Martínez García, 1989; van Ginkel \& Villa, 1991; Martínez Chacón et al., 2011; Villa et al., 2015). Nevertheless, the accurate dating of the numerous syntectonic detrital successions that exist in these areas, i.e. the Áliva Formation (Maas, 1974), had remained contentious as a consequence of the scarcity of fusulines and the remote location of the outcrops.

The present paper describes the stratigraphy and fusuline content of the unconformable succession cropping out in the sector of Hoyo Oscuro (Fig. 2; Supplementary Information Fig. 1), situated in the vicinity of the Vegas de Ándara (Ándara or Eastern Massif of the Picos de Europa mountains). In this relatively thin stratigraphic succession, siliciclastic strata, comprising abundant fusuline-bearing resedimented carbonates, and autochthonous limestones occur. Despite some general information of the outcrop was included in Merino-Tomé et al. (2009a, see data repository; and 2009b), its accurate biostratigraphy was so far unknown. Therefore, a main objective in present research was to establish the age of the several stratigraphic intervals exposed, and to correlate them with contemporaneous strata of the Ándara Massif and other areas of the Picos de Europa. This correlation is considered a necessary step for ascertaining the paleogeographic significance of the Hoyo Oscuro strata.

\section{STRATIGRAPHY OF THE HOYO OSCURO SYNTECTONIC STRATA}

The Hoyo Oscuro syntectonic strata unconformably overlie the upper Moscovian limestones of the Picos de Europa Formation. They are composed of both terrigenous packages with abundant lithoclastic breccias to packstones, similarly 
to the Áliva Formation, and autochthonous carbonates exhibiting microfacies similar to those of the Las Llacerias Formation. Three erosional unconformities recognized in this outcrop enabled us to subdivide the syntectonic succession into the four stratigraphic sequences described below (Fig. 3; Supplementary Information Figs 2-3):

\subsection{Sequence 1}

The base of the sequence is an irregular erosive surface with meter-scale relief, which most probably represents an angular unconformity according to the scarce dip data collected in the strata of both the Picos de Europa

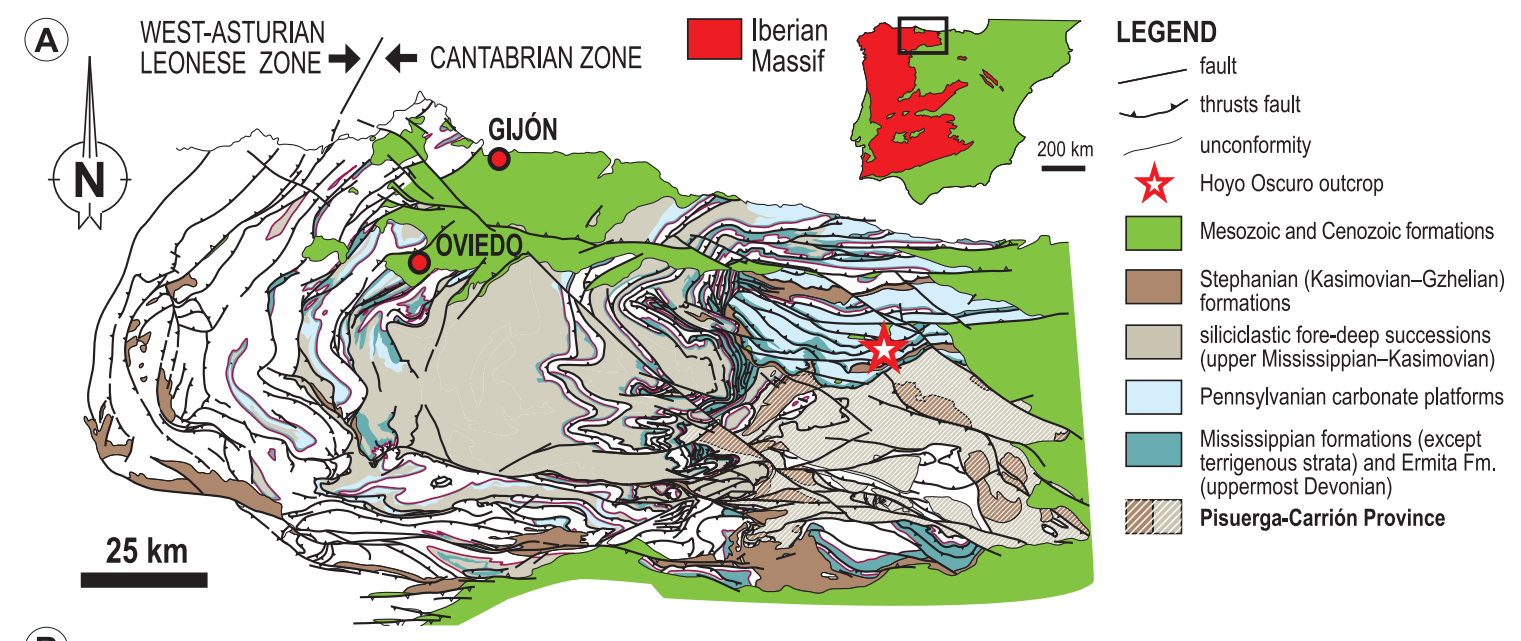

(B)

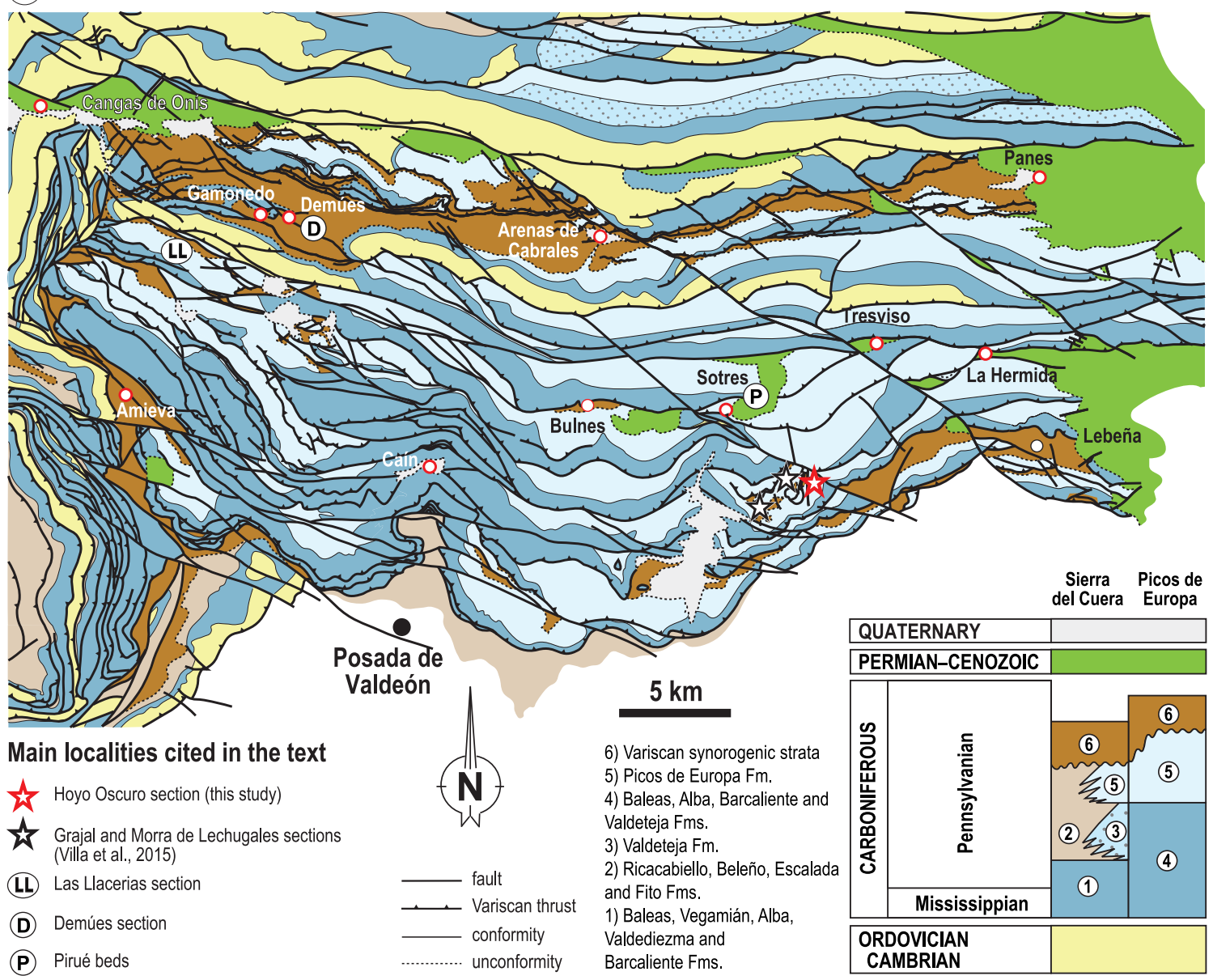

Figure 1. a) Schematic geological map of the Cantabrian Zone showing the location of the studied section. b) Synthetic geological map of the northeastern part of the Bodón-Ponga unit (sensu Alonso et al., 2009) showing the geology of the eastern part of the Ponga Nappe and Picos de Europa (modified from Merino-Tomé et al., 2009a). 
Formation, below, and the Sequence 1, above. This surface is overlain by an interval, up to $36 \mathrm{~m}$ thick, made of a clast-supported calcareous breccia containing locally abundant rip up shale clasts, which evolves into a capping laminated calclithite division. This basal breccia unit contains lithoclasts derived from the underlying Picos de Europa Formation and displays an internal structuring similar to that of the megaturbidites described by Labaume et al. (1987), being covered by up to $50 \mathrm{~m}$ of dark-gray shales with siderite nodules. The upper part of the shales includes an erosively based body of lithoclastic to bioclastic breccias and rud- to packstones arranged into meter- to decimeter-thick beds with erosive bases (see Supplementary Information Figs 3a-3b). This body is $44 \mathrm{~m}$ in thickness at its northern end, where it is truncated by a thrust fault, and thins southwards until wedging out within a distance of $250 \mathrm{~m}$. Finally, at the top of the sequence, the dark grey shales embed a ca. 20-m-thick and 130-m-long limestone slab formed by nodular bioclastic wacke- to packstones, resembling platform-top strata of the Picos de Europa Formation. Field relationships, lithology, shape and basal brecciation and shearing planes in the base of the slab permit to interpret it as slide block (olistolith).

\subsection{Sequence 2}

Sequence 2 rests unconformably on either the Sequence 1 or the Picos de Europa Formation strata, apparently overlapping the thrust fault described above (see Fig. 2; Supplementary Information Fig. 1). Sequence 2 is $24-\mathrm{m}$ thick, at least, and it rests on an irregular erosional surface overlying both the dark grey shales and the limestone slab block of Sequence 1. The lower $18 \mathrm{~m}$ consist of
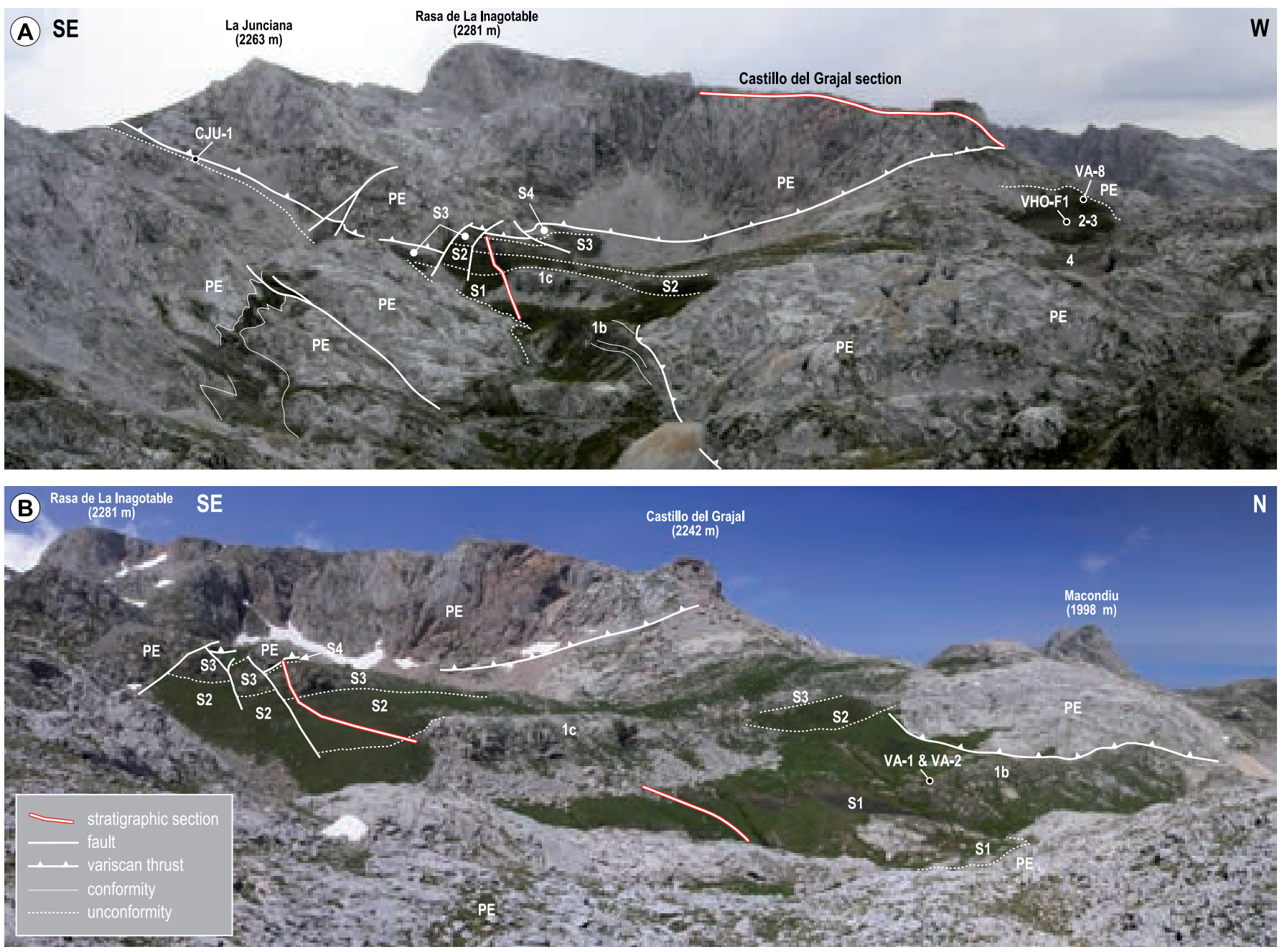

Figure 2. a) Panoramic view of the Hoyo Oscuro area showing the location of the fusuline samples CJU-1, VHO-F1, VA- 8 and of the sections of Hoyo Oscuro and Castillo del Grajal (the latter described by Villa et al., 2015). PE, Picos de Europa Formation; S1-S4, Sequence 1 to Sequence 4. b) Close-up view of the outcrop with the trace of the Hoyo Oscuro section and the location of fusuline samples VA-1 and VA-2 (1c: limestone olistolith). 
lithic sandstones with intercalated grey shales and minor polymictic conglomerates (Supplementary Information Fig. 3c); sandstone beds exhibit cross bedding (Supplementary Information Fig. 3d), contorted lamination and, in the upper part, contain frequent plant debris and burrowing. The uppermost part of Sequence 2 is formed by ca. $6 \mathrm{~m}$ of burrowed marlstones, and marly wacke- to floatstones with abundant brachiopods, corals (Cyathaxonia fauna), bryozoans, crinoids, gastropods, sphinctozoan sponges, phylloid algae and diverse foraminiferal associations (Fig. 3e).

\subsection{Sequence 3}

Sequence 3 is up to $27 \mathrm{~m}$ in thickness and can be subdivided into two different parts: the lower part (20 m thick) consists of calcareous (lithoclastic and bioclastic) breccias and rudto packstones forming meter- to decimeter-thick beds with erosive bases and normal grading. These beds are generally amalgamated, although decimeter-thick intercalations of burrowed marlstones and marly limestones occur towards the top (Supplementary Information Fig. 4a). At the base of the sequence, matrix-supported breccias with centimeter to decimeter-sized marlstone and shale intraformational clasts are common. Finally, the upper part of the sequence consists of grey marlstones and poorly bedded, darkgrey nodular and marly wacke- to packstones with a very rich and diverse biotic content. These marlstones include phylloid and Anthracoporella algae, colonial rugose and syringoporid corals (Supplementary Information Fig. 4b), sphinctozoan sponges, brachiopods, bryozoans and crinoids. Microfossils, including benthic foraminifers, are also abundant.

Southwards, in the northern slope of the La Junciana Peak (locality CJU-1), autochthonous limestone deposits, correlated to the upper part of the Sequence 3, unconformably overlie the strata of Picos de Europa Formation. Two productive fusuline samples (Fig. 2a; Supplementary Information Fig. 1) were collected from these beds.

\subsection{Sequence 4}

The base of Sequence 4 is an irregular erosional surface, with unequivocal karstic features, overlain by polymictic conglomerates and cross-bedded lithic sandstones with common bioclasts and calcareous lithoclasts (Supplementary Information Fig. 4c). This package shows remarkable thickness variations, which illustrate the irregular character of the basal unconformity, ranging from a few meters to centimeters at the location of the stratigraphic section shown in Fig. 2 to more than $30 \mathrm{~m}$ in the southernmost outcrops exposed in the slopes of the Hoyo Oscuro depression (Supplementary Information Fig. 4d).
The polymictic conglomerates contain calcareous, quartzitic and sandstone pebbles and boulders. The calcareous lithoclasts are derived from older Carboniferous formations of the Picos de Europa massifs, including intraclasts with microfacies typical of the Las Llacerias and Áliva Formations, and dark-colored cherts resembling those characterizing the toe-of-slope strata of the Pennsylvanian microbial carbonate platforms. The siliceous lithoclasts were most probably sourced from the CambroOrdovician Barrios Formation. This stratigraphic interval could be equivalent to the polymictic conglomerates that crop out patchily in the surroundings of the ruins of the Mazarrasa mine buildings located at the Vegas de Andara.

In the Hoyo Oscuro section, the clastic deposits of the lower part of Sequence 4 are overlain by $2.5 \mathrm{~m}$ of dark-grey and marly mud- to wackestones and 6-10 $\mathrm{m}$ of massive grey micritic limestones.

\section{DATING THE HOYO OSCURO FUSULINES AND CORRELATION. INFERENCES IN THE AGE OF THE VARISCAN DEFORMATION}

Fusuline samples from the Hoyo Oscuro section (Fig. 3), along with those from the nearby La Junciana slope locality (CJU-1; Fig. 2), allowed us to date and correlate each sequence with specific stratal packages of the Picos de Europa Formation, considered so far as pre-tectonic, and with the syntectonic Gamonedo deposits (Figs 1, 4).

\subsection{Fusulines from Sequence 1}

The clastic calcareous strata of Sequence 1 (samples VA-1 and VA-2) have yielded abundant specimens of Fusulinella alvaradoi and Fusulinella loresae (Figs 5a-i), typical upper Myachkovian forms belonging to the Fusulinella alvaradoi subzone of the Fusulinella Zone. Presence of the species $F$. aff. provecta reinforces this idea, since $F$. provecta was described by Sheng (1958) from the Myachkovian of the Penchi series, China. Sample VA-3, from the limestone olistolith at the top of the sequence, has yielded Fusulina aff. pankouensis (Figs 6a-6b), a fusuline species most probably late Myachkovian in age.

The fusuline assemblage of Sequence 1 can be correlated with those recorded in the upper part (not uppermost) of the Picos de Europa Formation from the Mazarrasa and Morra de Lechugales sections of the Ándara Massif (Villa et al., 2015, Figs 4-6), and in the syntectonic sequence 2 (Merino-Tomé et al., 2006) of the northern part of the Picos de Europa (Gamonedo area). Despite samples VA-1 and VA-2 are from lithoclastic breccias to packstones with clasts of the underlying Picos de Europa Formation, 

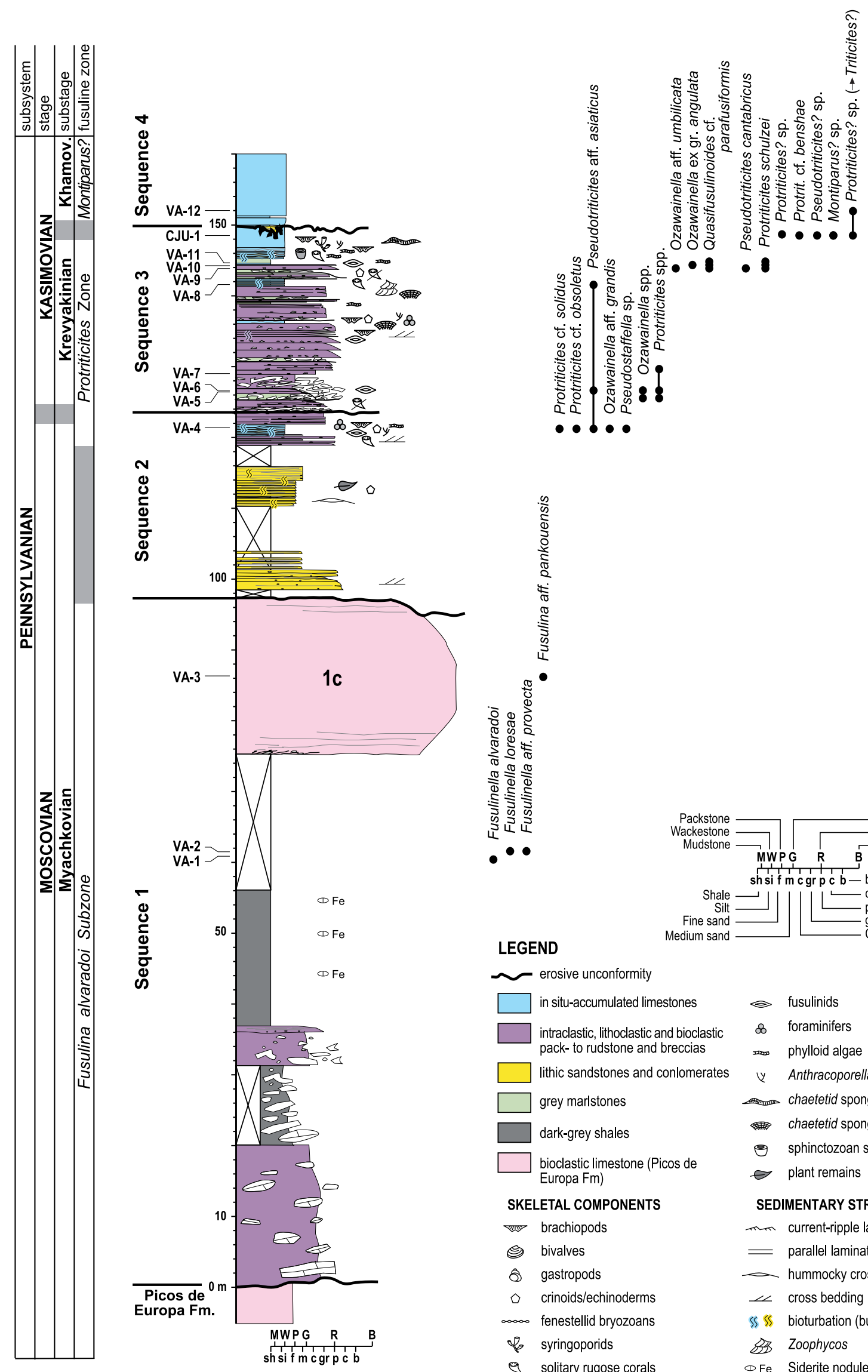

LEGEND

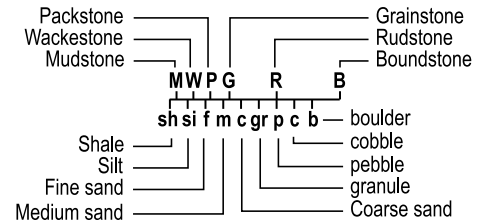

$\sim$ erosive unconformity

\begin{tabular}{|c|c|c|c|}
\hline & in situ-accumulated limestones & $\otimes$ & fusulinids \\
\hline & intraclastic, lithoclastic and bioclastic & 8 & foraminifers \\
\hline & pack- to rudstone and breccias & $\infty$ & phylloid algae \\
\hline & lithic sandstones and conlomerates & v & Anthracoporella \\
\hline & grey marlstones & 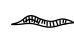 & chaetetid sponge colonies \\
\hline & dark-grey shales & 曲 & chaetetid sponge fragment \\
\hline & $\begin{array}{l}\text { bioclastic limestone (Picos de } \\
\text { Europa Fm) }\end{array}$ & $\theta$ & $\begin{array}{l}\text { sphinctozoan sponges } \\
\text { plant remains }\end{array}$ \\
\hline SKE & LETAL COMPONENTS & SED & IMENTARY STRUCTURES \\
\hline$\infty$ & brachiopods & Thm & current-ripple lamination \\
\hline$\theta$ & bivalves & $\overline{\overline{ }}$ & parallel lamination \\
\hline 8 & gastropods & $\infty$ & hummocky cross bedding \\
\hline$\bullet$ & crinoids/echinoderms & $\lll$ & cross bedding \\
\hline 00000 & fenestellid bryozoans & $\$ S \$ S$ & bioturbation (burrows) \\
\hline$\nLeftarrow$ & syringoporids & 235 & Zoophycos \\
\hline 9 & solitary rugose corals & $\Phi \mathrm{Fe}$ & Siderite nodules \\
\hline
\end{tabular}

Figure 3. Stratigraphic log of the Hoyo Oscuro section showing the sequences, the location of the studied samples and the distribution of fusuline species. The limestone slab at the top of Sequence 1 (1c) correspond to the limestone olistolith in Figure $2 \mathrm{~b}$. 
the observed features of the fusuline tests suggest that fusuline individuals were not reworked from older rocks, but most probably were coeval with sedimentation. This observation, along with the biostratigraphic data from sample VA-3, allows us to infer a late Myachkovian age for Sequence 1.

\subsection{Fusulines from Sequence 2}

The characteristics of these fusuline assemblages indicate an indeterminate position within the Moscovian/ Kasimovian transitional strata, an interval embracing the uppermost Myachkovian and/or the lowermost Krevyakinian. The fusulines from the upper part of the sequence (Pseudostaffella sp., primitive Protriticites, and Pseudotriticites aff. asiaticus) (Fig. 3) belong to the lowermost part of the Protriticites Zone, whose lower boundary lies below the current Moscovian/Kasimovian boundary. Comparing the biostratigraphic data from the VA-3 and VA-4 samples, it emerges that the limestone forming the olistolith at the top of Sequence 1 is only slightly older than the autochthonous limestones from the upper part of Sequence 2.

None of the fusulines yielded by this sequence have been found in other sections studied in the Ándara Massif. However, according to the primitive character of the Protriticites forms, they could be approximately contemporary with the species described from the base of the Protriticites Zone in the Castillo del Grajal and Silla de Caballo Bajero sections (Villa et al., 2015).

A comparison of the fusuline assemblages between the Hoyo Oscuro Sequence 2 and the lower sequence set from the Gamonedo area, northern part of the Picos de Europa (Merino-Tomé et al., 2006) points to a probable correlation with sequence 4 of the latter area.

\subsection{Fusulines from Sequence 3}

The Sequence 3, especially its upper half, contains the most productive fusuline-bearing beds of the Hoyo Oscuro section. Abundant specimens belonging to Protriticites, notably Protriticites schulzei Villa sp. nov. (Figs 7a-7r) occur at several levels along with isolated individuals of the genera Ozawainella, Pseudostaffella, Quasifusulinoides, and Pseudotriticites. The Protriticites species show an evolutionary degree similar to the forms occurring in the uppermost part of the Picos de Europa Formation in the Castillo del Grajal and Silla de Caballo Bajero sections (Villa et al., 2015) (Fig. 4).

The materials collected from the nearby La Junciana locality (samples CJU-1A and CJU-1B) belong to the uppermost part of Sequence III. The species collected from this locality (e.g. Protriticites cf. benshae) are comparable to forms from Las Llacerias Formation occurring in the Mazarrasa and Picos del Jierro sections (Fig. 4). Of special note is Montiparus? sp. (Figs 8j-8k), characterized by a relatively large shell, thick tectoria, and a wall microstructure exhibiting a dark, almost negligible diaphanotheca that may be even absent in the outer whorls, so giving the appearance of a three-layered wall; moreover, in the outer volutions all layers are pierced by pores. Such type of microstructure suggests an evolutionary stage not far from typical Montiparus. Also significant is the occurrence of Protriticites? sp. (Triticites?), which exhibits an advanced evolutionary degree (see discussion in the chapter on Systematics).

Sequence 3 is assigned to the Protriticites Zone (excluding its lowermost part) and correlated with the Krevyakinian, although its uppermost part could reach the Krevyakinian/Khamovnikian transition. As regards the stratigraphy established in the northern part of the Picos de Europa (Merino-Tomé et al., 2006), this sequence appears to be correlated with sequence 6 of the Gamonedo area.

\subsection{Fusulines from Sequence 4}

The youngest strata of the Hoyo Oscuro section only yielded a few poorly orientated fusuline specimens (sample VA-12) whose taxonomic position is unclear. Among them, Protriticites? sp. (Triticites?) (Fig. 8k) is reminiscent in shape of shell and wall microstructure of specimens questionably assigned to Triticites? sp. by Sánchez de Posada et al. (1999, 2002). The latter were found in the upper part of the Demués section (syntectonic succession of the Gamonedo area, northern part of the Picos de Europa), in a bed belonging to the upper part of sequence 7 (Merino-Tomé et al., 2006), probably earliest Khamovnikian in age.

Following these observations, the Sequence 4 of the Hoyo Oscuro section is tentatively placed in the lowermost part of the Montiparus Zone. Therefore, the age of these beds might be earliest Khamovnikian. Strata of this interval have never been found in the Ándara Massif (southeastern and eastern Picos de Europa), thus the Sequence 4 cannot be correlated with any stratigraphic interval previously studied in this massif. With respect to the sequences established in the Gamonedo syntectonic succession of northern Picos de Europa, Sequence 4 of Hoyo Oscuro is most probably correlated with the above-mentioned sequence 7 of Merino-Tomé et al. (2006).

\subsection{Fusulines and age of the earliest Variscan deformation}

Reconstructing the tectonic evolution of the Picos de Europa imbricate thrust system, eastern part of the Bodón-Ponga Unit (Alonso et al., 2009), is of key relevance to correctly interpret the last stages of the Variscan deformation in the 


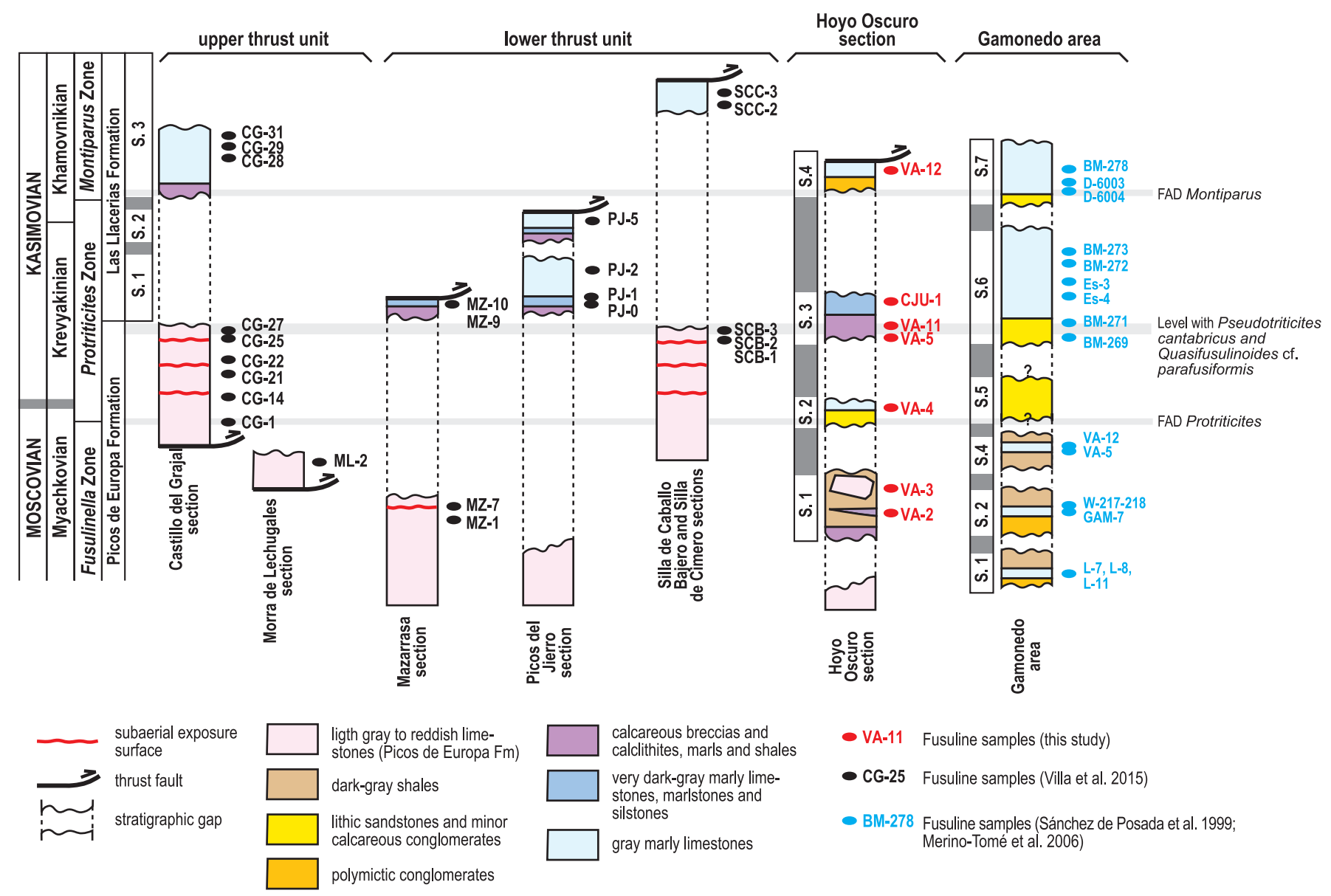

Figure 4. Tentative correlation chart of the sequences from the Hoyo Oscuro section with strata of other areas of Picos de Europa.

Cantabrian Zone and to date the development of the IberoArmorican Arc (Merino-Tomé et al., 2009a). Nevertheless, despite the significant progress achieved in recent years, our knowledge on the development of the imbricate thrust system was limited due to the lack of direct biostratigraphic dating of the oldest syntectonic strata (Áliva Formation) preserved in the central and southern areas of the Picos de Europa. The recycled character of the carbonate rocks, included as clasts in these successions, and the lack of findings of autochthonous-fusuline-bearing strata, made their dating to rely only on indirect evidence. In this way, an early Kasimovian (late Krevyakinian) age was interpreted for the base of the Áliva Formation on the basis of the youngest fusuline-bearing strata recorded in the Picos de Europa Formation in localities such as Las Llacerias (Villa, 1995; van Ginkel \& Villa, 1999; Villa \& van Ginkel, 2000; Cózar et al., 2007) and the Castillo del Grajal (Villa et al., 2015), which were considered as accumulated in the stable (pre-tectonic) carbonate platform developed ahead of the orogenic front (Merino-Tomé et al., 2009a, 2009b).

In this context, the present study is of great relevance since it provides the first direct biostratigraphic dating of the syntectonic succession by means of fusuline assemblages found in both clastic deposits, comparable to the Áliva Formation, and autochthonous carbonates, similar to those of the Las Llacerias Formation. In particular, biostratigraphic dating of the lowermost sequence in the Hoyo Oscuro section indicates that the oldest unconformable syntectonic strata in the southern and central parts of Picos de Europa are late Myachkovian in age, which agrees with Martínez-García \& Villa (1999) conclusions after dating the Pirué Beds in the vicinity of Sotres. These data evidence that the advance of the Variscan orogenic front towards the foreland was faster than previously envisaged and that the onset of tectonic activity in the distalmost preserved areas of the Cantabrian Zone basin started during latest Myachkovian, instead of late Krevyakinian, as currently accepted (Merino-Tomé et al., 2009a, 2009b). These new data invite to revise the currently accepted hypothesis about the development and evolution of the Picos de Europa imbricate thrust system, and are also of relevance for future studies of the last stages of Variscan deformation including the closure of the Ibero-Armorican Arc. 


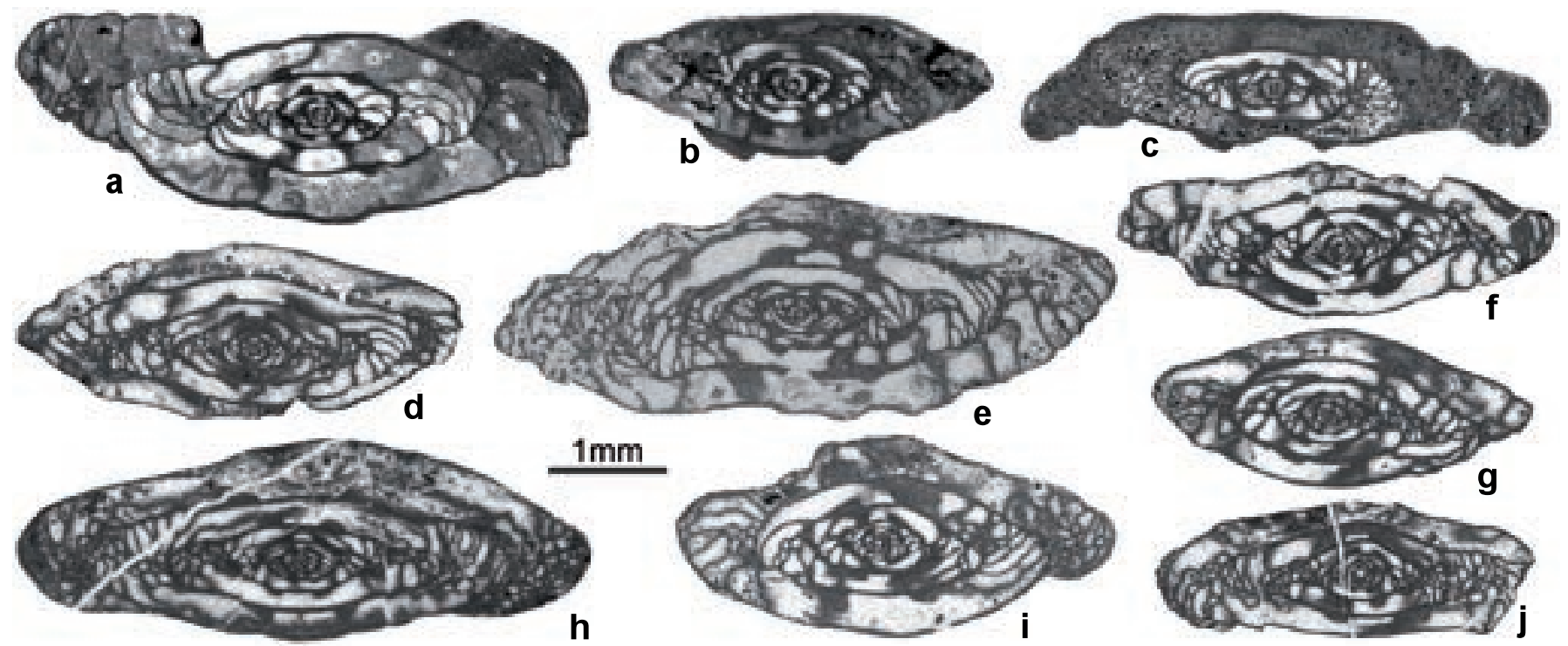

Figure 5. Fusulines of the Sequence I, upper Fusulinella Zone. Upper Myachkovian. a-c) Fusulinella alvaradoi van Ginkel, 1965. (a) VA1/1; (b) VA1/4; (c) VA1/3. d-i) Fusulinella loresae van Ginkel, 1965. (d) VA2/2a; (e) VA2/8; (f) VA2/2b; (g) VA2/1a; (h) VA2/10; (i) VA2/1b. j) Fusulinella aff. provecta Sheng, 1958, VA2/7.

\section{SYSTEMATIC PALAEONTOLOGY}

Family Ozawainellidae Thompson \& Foster, 1937

Genus Ozawainella Thompson, 1935

Type species Fusulinella angulata Colani, 1924

Ozawainella aff. grandis Potievskaya, 1958 (Fig. 6j)

Measurements. $\mathrm{L}=0.52 \mathrm{~mm} ; \mathrm{D}=1.43 \mathrm{~mm}$; $/ \mathrm{D}=$ $0.36 ; \mathrm{n}=6 ; \mathrm{d}=55 \mu \mathrm{m} ; \mathrm{D}_{\mathrm{IV}}=0.68 \mathrm{~mm} ; \mathrm{wth}=30 \mu \mathrm{m}$.

Remarks. The most outstanding features of this specimen are the large shell, extended keel and concave lateral sides in the last 1.5 volutions, as well as the umbilical depressions in the last two whorls. With respect to the shell size and presence of umbilical depressions, the species may be compared to Ozawainella grandis Potievskaya, 1958, from which, however, clearly differs in having concave lateral sides.

Stratigraphic data and age. Sample VA-4, Protriticites Zone (lowermost part), Moscovian/Kasimovian transition interval.

Ozawainella aff. umbilicata Grozdilova \& Lebedeva, 1950 (Fig. 7x)
Measurements. $\mathrm{L}=0.47 \mathrm{~mm} ; \mathrm{D}=0.92 \mathrm{~mm} ; \mathrm{L} / \mathrm{D}=$ $0.51 ; \mathrm{n}=6 ; \mathrm{d}=40 \mu \mathrm{m} ; \mathrm{D}_{\mathrm{IV}}=0.49 \mathrm{~mm} ; \mathrm{wth}=20 \mu \mathrm{m}$.

Remarks. The characteristics of this specimen fit well with those of the form described by Grozdilova \& Lebedeva (1950) as Ozawainella angulata umbilicata, only differing in having a slightly larger shell.

Stratigraphic data and age. Sample VA-10, Protriticites Zone, lower Kasimovian (Krevyakinian).

Ozawainella ex gr. angulata (Colani, 1924) (Fig. 7y)

Measurements. $\mathrm{L}=0.50 \mathrm{~mm} ; \mathrm{D}=1.33 \mathrm{~mm} ; \mathrm{L} / \mathrm{D}=$ $0.38 ; \mathrm{n}=6 ; \mathrm{d}=45 \mu \mathrm{m} ; \mathrm{D}_{\mathrm{IV}}=0.64 \mathrm{~mm} ; \mathrm{wth}=20 \mu \mathrm{m}$.

Remarks. Specimen exhibiting a large shell, large diameter, pointed and stretched median region, straight lateral sides and flattened umbilical regions. It recalls forms usually included within the Ozawainella ex gr. angulata species group, of which the Cantabrian species could be one of the largest representatives.

Stratigraphic data and age. Sample VA-11, Protriticites Zone, lower Kasimovian (Krevyakinian).

Genus Pseudostaffella Thompson, 1942

Type species Pseudostaffella needhami Thompson, 1942 


\section{Pseudostaffella sp.}

(Fig. 6i)

Measurements. $\mathrm{L}=0.69 \mathrm{~mm} ; \mathrm{D}=0.89 \mathrm{~mm} ; \mathrm{L} / \mathrm{D}=$ $0.77 ; \mathrm{n}=6 ; \mathrm{d}=50 \mu \mathrm{m} ; \mathrm{D}_{\text {IV }}=0.45 \mathrm{~mm} ; \mathrm{wth}=20 \mu \mathrm{m}$.

Remarks. Small Pseudostaffella specimen that probably should be assigned to Quasistaffella Solovieva, the latter considered as a subgenus, as discussed by Villa et al. (2015; p. 273). Besides its small size, the massive ribbon-like chomata and slight umbilical depressions developed in the last two volutions are its most remarkable features. Small Pseudostaffella of this kind occur in isolation in strata from the Moscovian/Kasimovian transition and lower Krevyakinian.

Stratigraphic data and age. Sample VA-4, Protriticites Zone (lowermost part), Moscovian/Kasimovian transition interval.

Family Fusulinidae von Möller, 1878

Genus Fusulinella, von Möller, 1877

Type species Fusulinella bocki von Möller, 1878
Fusulinella alvaradoi van Ginkel 1965

(Figs 5a-5c)

Measurements. $\mathrm{L}=4.90 \mathrm{~mm} ; \mathrm{D}=1.95 \mathrm{~mm} ; \mathrm{L} / \mathrm{D}=$ $2.51 ; \mathrm{n}=6 ; \mathrm{d}=10 \mu \mathrm{m} ; \mathrm{D}_{\mathrm{IV}}=1.75 \mu \mathrm{mm} ; \mathrm{wth}=20 \mu \mathrm{m}$.

Remarks. Shell characterized by a tiny proloculus, tightly coiled juvenarium and a rapid expansion of the three last volutions. Low, narrow chomata. Tunnel opening very wide. Thin four-layered wall. This is a species belonging to the F. schwagerinoides group occurring commonly in the Cantabrian Zone.

Stratigraphic data and age. Picos de Europa Formation, sample VA-1, Fusulinella Zone (F. alvaradoi subzone), Moscovian (upper Myachkovian).

Fusulinella loresae van Ginkel 1965

(Figs 5d-5i)

Measurements. $\mathrm{L}=3.25-5.55 \mathrm{~mm} ; \mathrm{D}=1.35-1.85 \mathrm{~mm}$; $\mathrm{L} / \mathrm{D}=2.41-3.19 ; \mathrm{n}=6-6.5 ; \mathrm{d}=10-45 \mu \mathrm{m} ; \mathrm{D}_{\mathrm{IV}}=0.55-$ $0.58 \mathrm{~mm}$; wth $=35 \mu \mathrm{m}$.

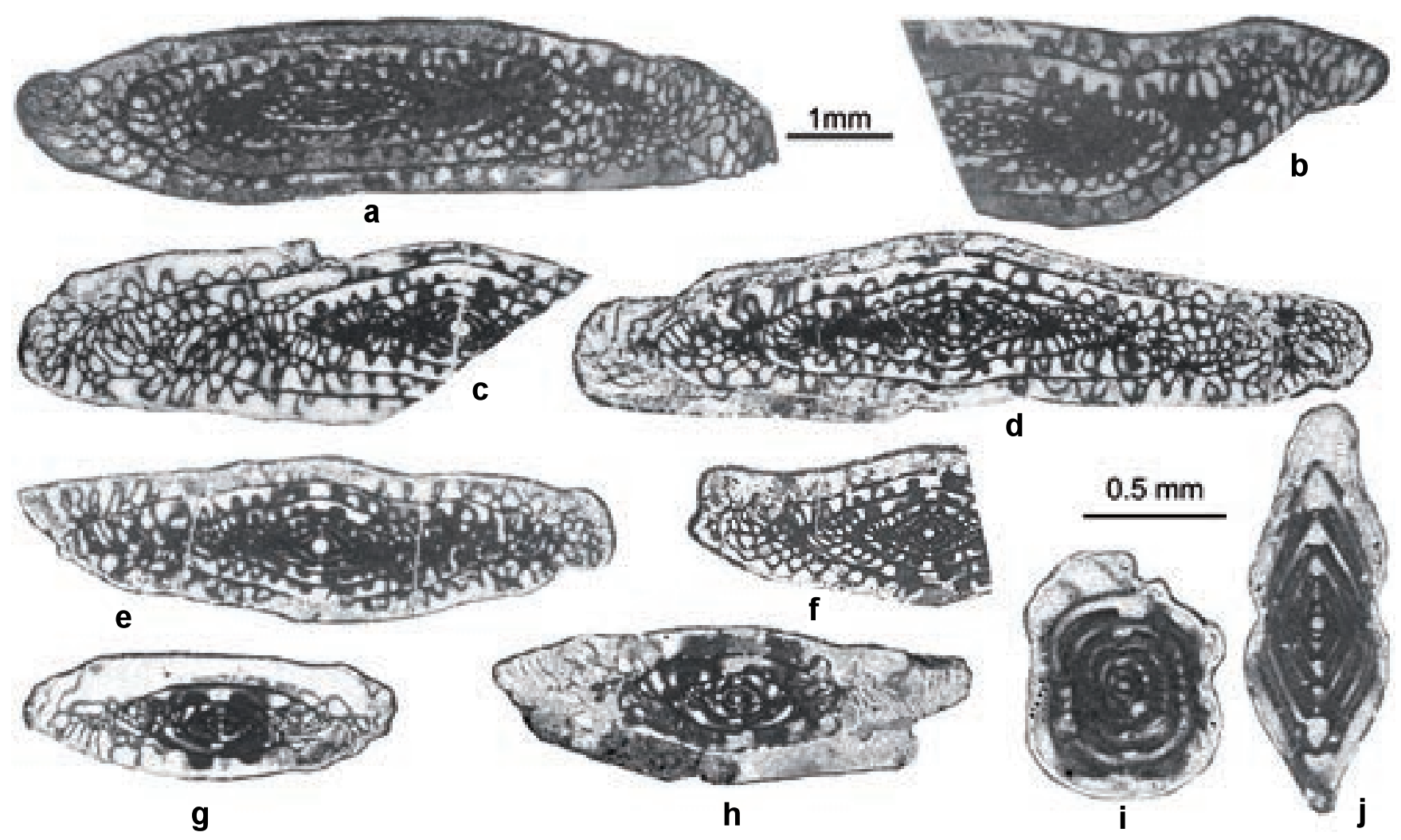

Figure 6. Fusulines of the Sequence II, base of the Protriticites Zone. Uppermost Myachkovian to Myachkovian/Kasimovian transitional interval. a-b) Fusulina aff. pankouensis Lee, 1927. (a) VA3/1; (b) VA3/3. c-f) Pseudotriticites aff. asiaticus Bensh, 1972. (c) VA4/12; (d) VA4/9; (e) VA4/13; (f) VA4/14. g) Protriticites cf. obsoletus (Schellwien, 1908), VA4/19. h) Protriticites cf. solidus, (Rjazanov, 1958), VA4/17. i) Pseudostaffella sp., VA4/7. j) Ozawainella aff. grandis, Potievskaja, 1958, VA4/5. 
Remarks. Fusulinella loresae is another Cantabrian Zone species exhibiting characteristics typical of the $F$. schwagerinoides species group. It can be distinguished from Fusulinella alvaradoi van Ginkel by having a tighter spire (cf. diameter of corresponding whorls).

Stratigraphic data and age. Picos de Europa Formation, sample VA-2, Fusulinella Zone (F. alvaradoi subzone), Moscovian (upper Myachkovian).

\section{Fusulinella aff. provecta Sheng, 1958}

(Fig. 5j)

Measurements. $\mathrm{L}=3.25 \mathrm{~mm} ; \mathrm{D}=1.20 \mathrm{~mm} ; \mathrm{L} / \mathrm{D}=$ $2.71 ; \mathrm{n}=5.5 ; \mathrm{d}=90 \mu \mathrm{m} ; \mathrm{D}_{\mathrm{IV}}=0.66 \mathrm{~mm} ; \mathrm{wth}=30 \mu \mathrm{m}$.

Remarks. The most distinct features of this specimen are its subcylindrical test, gently vaulted median region, rounded polar ends, and massive and asymmetric chomata, which tend to be quadrangular in shape. For the size of the shell, L/D ratio and type of chomata, it recalls Fusulinella provecta Sheng, which, however, differs from our specimen in not having rounded, but acute polar ends.

Stratigraphic data and age. Picos de Europa Formation, sample VA-2, Fusulinella Zone ( $F$. alvaradoi subzone), Moscovian (upper Myachkovian).

\section{Genus Protriticites Putrja, 1948}

Type species Protriticites globulus Putrja, 1948

\section{Protriticites cf. obsoletus (Schellwien, 1908)}

(Fig. 6g)

Measurements. $\mathrm{L}=3.70 \mathrm{~mm} ; \mathrm{D}=1.25 \mathrm{~mm} ; \mathrm{L} / \mathrm{D}=$ $2.96 ; \mathrm{n}=4.5 ; \mathrm{d}=70 \mu \mathrm{m} ; \mathrm{D}_{\mathrm{IV}}=0.70 \mathrm{~mm} ; \mathrm{wth}=40 \mu \mathrm{m}$.

Remarks. The most relevant features in this single specimen are its rather loosely coiled outer volutions, slightly fluted septa, well-developed quadratic chomata (in the inner whorls), and a thin four-layered wall that is poorly differentiated, although thin tectoria and a grey diaphanotheca pierced by weak pores can be observed in parts. Shape and size of shell, septal fluting and type of chomata conform to Protriticites obsoletus (Schellwien, 1908), but the microstructure of the wall seems to be less evolved than in typical specimens of this species. For this reason, it is considered as probably being a primitive representative of the species and of the genus, close to the forms that Remizova (1992) transferred to her genus Praeobsoletes.

Stratigraphic data and age. Sample VA-4, Protriticites Zone (lowermost part), Moscovian/Kasimovian transition interval.

\section{Protriticites cf. solidus (Rjazanov, 1958)}

(Fig. 6h)

Measurements. $\mathrm{L}=4.65 \mathrm{~mm} ; \mathrm{D}=1.50 \mathrm{~mm} ; \mathrm{L} / \mathrm{D}=$ $3.10 ; \mathrm{n}=5 ; \mathrm{d}=85 \mu \mathrm{m} ; \mathrm{D}_{\mathrm{IV}}=0.90 \mathrm{~mm} ; \mathrm{wth}=40 \mu \mathrm{m}$.

Remarks. For its flattened-fusiform shape, bluntpointed polar ends, massive chomata, present in inner and intermediate volutions, and a thin four-layered wall exhibiting tectoria, tectum and grey diaphanotheca pierced by thin pores, this specimen recalls Protriticites solidus (Rjazanov, 1958), originally described from the $\mathrm{N}_{2}$ limestone of the Donbass.

Stratigraphic data and age. Sample VA-4, Protriticites Zone (lowermost part), Moscovian/Kasimovian transition interval.

\section{Protriticites schulzei Villa sp. nov. (Figs 7a-7r)}

Derivatio nominis. The species is dedicated to the Mexican geologist (of German origin) Gustavo Schulze, who in 1907 discovered the fusuline-bearing strata of the Ándara Massif and used these fossils to estimate the stratigraphic position and correlation of the Ándara limestones. His very advanced geological study of the Picos de Europa massifs was never published and remained unknown for more than 80 years, until his field notebooks were discovered.

Measurements. 12 mature specimens. $\mathrm{L}=4.50-6.40$ $\mathrm{mm}(\mathrm{avg}=5.71 \mathrm{~mm}) ; \mathrm{D}=1.65-2.50 \mathrm{~mm}(\operatorname{avg}=2.01$ $\mathrm{mm}) ; \mathrm{L} / \mathrm{D}=2.04-2.95(\mathrm{avg}=2.74) ; \mathrm{n}=5-6.5(\mathrm{avg}=$ $5.3) ; \mathrm{d}=70-160 \mu \mathrm{m}(\operatorname{avg}=122 \mu \mathrm{m}) ; \mathrm{D}_{\mathrm{IV}}=0.88-1.50 \mathrm{~mm}$ (avg $=1.17 \mathrm{~mm}) ;$ wth $=40-70 \mu \mathrm{m}(\operatorname{avg}=55 \mu \mathrm{m}) .($ avg $=$ average). Holotype (specimen VA9/2; Fig. 7f): $\mathrm{L}=6.25$ $\mathrm{mm} ; \mathrm{D}=2.50 \mathrm{~mm} ; \mathrm{L} / \mathrm{D}=2.50 ; \mathrm{n}=6 ; \mathrm{d}=60 \mu \mathrm{m} ; \mathrm{D}_{\mathrm{IV}}=$ $1.30 \mathrm{~mm} ; \mathrm{wth}=60 \mu \mathrm{m}$.

Material. 15 axial, 4 almost axial, and 6 slightly oblique sections. The material is stored in the Department of Geology, University of Oviedo.

Diagnosis. Shell fusiform; median region from slightly convex to almost flat. Septa moderately folded in their polar ends. Chomata of variable shape, narrower in the outer volutions. Mature walls showing four-layered wall, pierced by weak pores.

Description. Test of rather variable shape, from inflated (VA10/1a; Fig. 7g) to elongate (VA11/6b; Fig. 7c) fusiform, frequently exhibiting a flattened median region (VA10/10a; Fig. 7j). Polar ends usually blunt-pointed, more rarely pointed. Spiral rapidly increasing in height in the last 


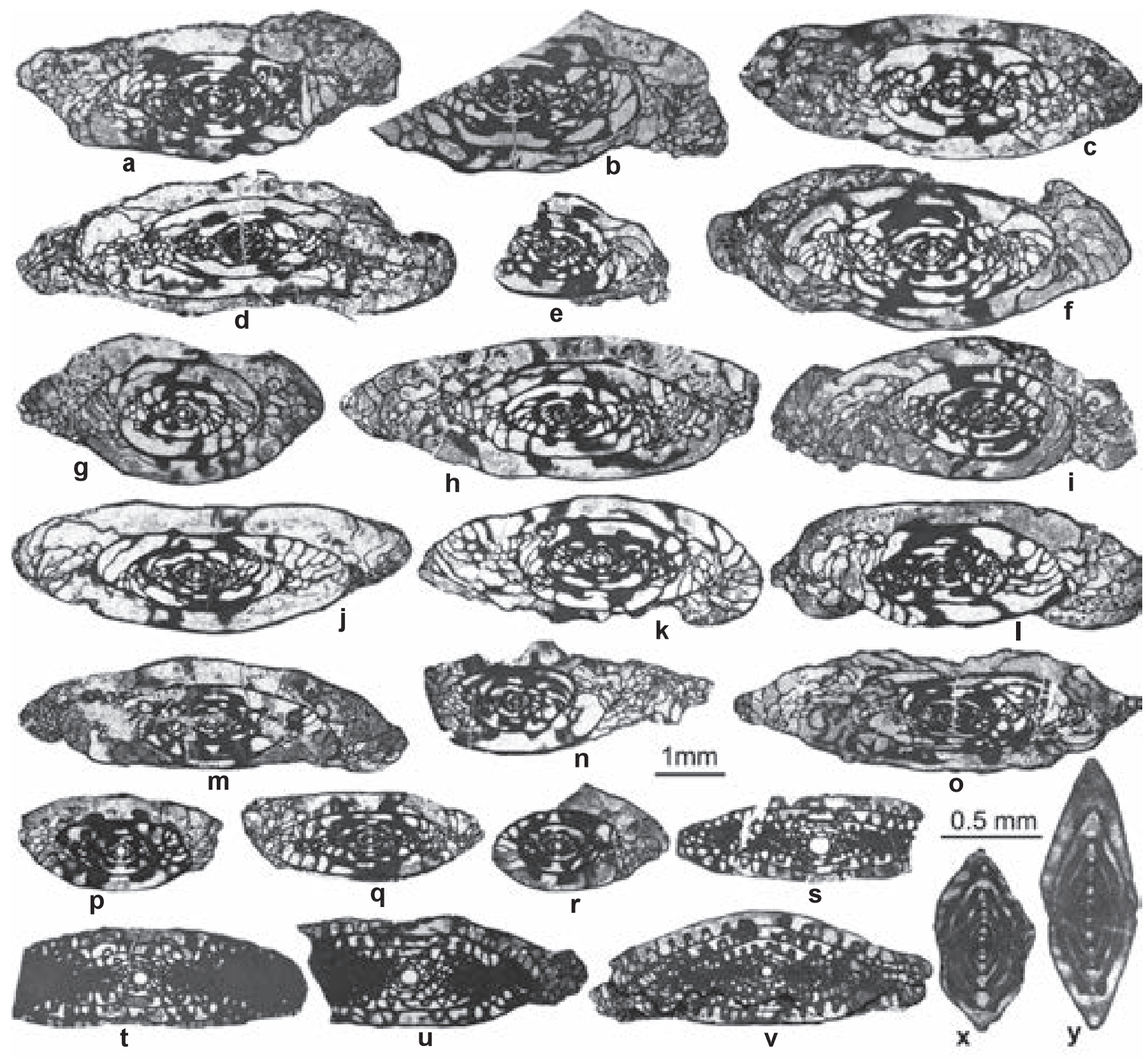

Figure 7. Fusulines of the lower part of Sequence III, Protriticites Zone. Krevyakinian. a-r) Protriticites schulzei Villa sp. nov. (a) VA11/1a; (b) VA11/5; (c) VA11/6b; (d) VA11/11; (e) VA11/4; (f) VA9/2; (g) VA10/1; (h) VA9/6; (i) VA11/6a; (j) VA10/10; (k) VA11/3; (l) VA10/1; (m) VA10/11; (n) VA10/6; (o) VA9/9; (p) VA11/17; (q) VA11/17; (r) VA11/8. s-u) Quasifusulinoides cf. parafusiformis Bensh, 1969. (s) VA9/13; (t) VA11/1b; (u) VA10/13. v) Pseudotriticites cantabricus Villa in Villa et al. (2015), VA10/7. x) Ozawainella aff. umbilicata Grozdilova \& Lebedeva, 1950, VA10/5. y) Ozawainella ex gr. angulata (Colani, 1924), VA11/16.

volutions. Septa moderately folded, usually only in their polar ends, more rarely exhibiting weak undulations in the median region. Chomata rather variable both in width and height; they are asymmetric, often subquadratic, more massive in intermediate whorls. Wall very variable, usually three-layered in the three innermost whorls and four-layered (exhibiting a faint diaphanoteca) from the volution three and a half onwards; although the last type of microstructure is most common in our material, there are specimens in which the diaphanotheca is either not visible or only visible in the penultimate whorl. The wall is pierced by weak pores, sometimes only visible in parts. Very thin partitions of the chamber space (phrenotecae?) occur occasionally in some specimens (e.g. Figs 7d, 7f-7g, 7j).

Discussion. Protriticites schulzei sp. nov. resembles some Paleotethyan species, particularly Protriticites pramollensis (Pasini, 1963) and Protriticites variabilis 
Bensh, 1972. P. pramollensis, described from the Carnic Alps, differs from $P$. schulzei in having a smaller size (maximum length and outer diameter measured in Pasini specimens are $5.07 \mathrm{~mm}$ and $1.66 \mathrm{~mm}$, respectively, whereas the average of these parameters in $P$. schulzei is $5.71 \mathrm{~mm}$ and $2.01 \mathrm{~mm}$. Also the coiling is looser in $P$. schulzei than in $P$. pramollenis, as we observe comparing diameter values for corresponding whorls. Microspheric specimens were not found in the Cantabrian form. As regards $P$. variabilis, $P$. schulzei is also larger in size, has a looser spire, and more variable chomata, which in some specimens are much broader than in $P$. variabilis.

Stratigraphic data and age. Sample VA-9, VA10, and VA-11, Protriticites Zone, lower Kasimovian (Krevyakinian, probably the upper part).

\section{Protriticites cf. benshae Villa in Villa et al., 2015 (Figs 8a-8b, 8f-8h)}

Measurements. $\mathrm{L}=2.45-4.75 \mathrm{~mm} ; \mathrm{D}=1.10-1.48$ $\mathrm{mm} ; \mathrm{L} / \mathrm{D}=2.04-3.39 ; \mathrm{n}=4-5 ; \mathrm{D}_{\mathrm{IV}}=0.80-1.20 ; \mathrm{d}=8.0$ $10 \mu \mathrm{m} ; \mathrm{wth}=30 \mu \mathrm{m}$.

Remarks. Most characteristics of the available specimens conform $P$. benshae, described by Villa et al., 2015 (p. 280-281) from the Las Llacerias Formation of the Mazarrasa and Picos del Jierro sections of the Ándara Massif. The phrenothecae, a feature observed in the type material, although less conspicuous, is also present in the Hoyo Oscuro specimens (Fig. 8h).

Stratigraphic data and age. Sample CJU-1, locality situated slightly southwards the Hoyo Oscuro section, in the northern slope of La Junciana Peak. Bed probably belonging to the uppermost part of the Protriticites Zone, or, most probably, within the Protriticites/Montiparus transition. Kasimovian (either uppermost Krevyakinian, or base of the Khamovnikian). [Note: Protriticites cf. benshae occurs along with fusuline fragments questionably assigned to Pseudotriticites, Protriticites, and Montiparus, too poor for a formal description. The latter (Montiparus? sp.) is illustrated in Figures 8d-8e].

\section{Protriticites? sp. (Triticites?)}

(Figs 8i-8k)

Measurements. $\mathrm{L}=5.80-6.80 \mathrm{~mm} ; \mathrm{D}=2.00-2.25 \mathrm{~mm}$; $\mathrm{L} / \mathrm{D}=2.9-3.02 ; \mathrm{n}=5 ?-7 ; \mathrm{d}=80-90 \mu \mathrm{m} ; \mathrm{D}_{\mathrm{IV}}=0.70-0.77$ $\mathrm{mm} ; \mathrm{wth}=30-45 \mu \mathrm{m}$.

Remarks. Wall consists of tectum, a dark grey discontinuous diaphanotheca, and very thin (sometimes absent) tectoria, pierced by weak pores. Compared to typical representatives of Protriticites, these specimens show a wall considerably thinner. This wall microstructure is similar to Triticites? sp. described from the Demués section (northern part of Picos de Europa) from a bed of probable Khamovnikian age (Sánchez de Posada et al., 1999). According to these authors, Triticites? sp. could be a descendant of latest Moscovian/earliest Kasimovian thin-walled species that are considered as primitive Protriticites (van Ginkel \& Villa, 1999), or as members of the genus Praeobsoletes Remizova (Remizova, 1992). However, the massive chomata (both in the Demúes and the Ándara specimens) call to mind the characteristics of the lineage leading from Protriticites to Montiparus. To summarize, specimens show features reminiscent of three genera: four-layered wall in some whorls as in Protriticites, large size (some specimens) and a thin two-layered wall in outer volutions as in Triticites, and large size and strong chomata as in Montiparus. Unfortunately, the available material is too scarce for a definitive conclusion. Anyway, the large size of some specimens (individuals from Demués illustrated by Sánchez de Posada et al., 1999, reach up to $8 \mathrm{~mm}$ in length), coupled with their stratigraphic position (well above beds containing typical Protriticites), suggests a position close to the base of the Montiparus Zone.

Stratigraphic data and age. Samples CJU-1 A y CJU-1B, La Junciana locality, and sample VA-12, Hoyo Oscuro section, beds probably ranging from the uppermost Protriticites Zone to the base of the Montiparus Zone. Kasimovian (uppermost Kreviakinian to base of the Khamovnikian).

Genus Fusulina Fisher de Waldheim, 1829

Type species Fusulina cylindrica Fisher de Waldheim, 1829

\section{Fusulina aff. pankouensis Lee, 1927}

(Figs 6a-6b)

Measurements. $\mathrm{L}=7.80-8.60 \mathrm{~mm} ; \mathrm{D}=1.70-1.90 \mathrm{~mm}$; $\mathrm{L} / \mathrm{D}=4.11-5.06 ; \mathrm{wth}=40-45 \mu \mathrm{m}$.

Remarks. The two specimens available have a slender test with blunt-pointed to rounded polar ends and flat median region. One specimen is subcylindrical and the other has a curved axis of coiling. The spire expands very slowly and uniformly. Septa are folded, forming fairly regularly distributed arches; the septal folding increases in height from the median region, where the arches are low, to the polar ends. Thick calcite deposits occur on the base of the chambers along the axis of the intermediate whorls. Chomata low and narrow, visible in the inner whorls. Wall three-layered, very thin and consisting of tectum, a white and clear diaphanotheca, and a much darker and comparatively thick inner tectorium; a thin but doubtful 
outer tectorium could exist in the inner volutions. The wall of the outer volutions is pierced by thin pores. All these characters remind those of Fusulina pankouensis Lee, 1927, and F. pankouensis okensis Rauzer-Chernousova in Rauzer-Chernousova et al. (1951). Although the poor material available hampers a closer comparison, Fusulina aff. pankouensis seems to differ from both the Chinese and the Russian form in having a larger test, simpler wall (three layers in most of the volutions instead of four) and, although not visible, probably a smaller proloculus. For its wall microstructure, this species is considered to belong to a lineage leading from Fusulina to Quasifusulinoides.

Stratigraphic data and age. Sample VA-3, Fusulinella Zone (uppermost $F$. alvaradoi subzone), Moscovian (upper Myachkovian).

Genus Quasifusulinoides Rauzer-Chernousova \& Rozovskaja in Miklukho-Maklay et al., 1959

Type species Pseudotriticites fusiformis Rozovskaja, 1952

Quasifusulinoides cf. parafusiformis Bensh, 1969

(Figs $7 \mathrm{~s}-7 \mathrm{u}$ )

Measurements. $\mathrm{L}=4.00-5.20 \mathrm{~mm} ; \mathrm{D}=1.30-1.55 \mathrm{~mm}$; $\mathrm{L} / \mathrm{D}=3.01-3.35 ; \mathrm{n}=4.5-5 ; \mathrm{d}=240-280 \mu \mathrm{m} ; \mathrm{D}_{\mathrm{IV}}=1.08-$ $1.35 \mathrm{~mm}$; wth $=35-40 \mu \mathrm{m}$.

Remarks. Elongate, fusiform to subcylindrical test, with flat median region and blunt-pointed polar ends. Septa irregularly folded, the loops increasing in height towards the polar ends. Chomata developed only on the proloculus. Axial fillings moderately developed. Wall is thin, consisting of tectum, diaphanotheca and inner tectorium. Pores are clearly visible in parts. Although the specimens are broken, which hampers a proper comparison, they probably belong to $Q$. fusiformis, a species already found in the Picos de Europa Formation of the Ándara Massif (Villa et al., 2015).

Stratigraphic data and age. Samples VA-9, VA-10, VA11, Protriticites Zone, lower Kasimovian (Krevyakinian).

Genus Pseudotriticites Putrja, 1940

Type species Fusulina donbassica Putrja, 1939

Pseudotriticites aff. asiaticus Bensh, 1972

(Figs 6c-6f)

Measurements. $\mathrm{L}=5.50-8.30 \mathrm{~mm} ; \mathrm{D}=1.50-2.00 \mathrm{~mm}$; $\mathrm{L} / \mathrm{D}=3.61-4.45 ; \mathrm{n}=5.5-7 ; \mathrm{d}=140-210 \mu \mathrm{m} ; \mathrm{D}_{\mathrm{IV}}=0.68-$ $1.12 \mathrm{~mm}$; wth $=25-40 \mu \mathrm{m}$.
Description. Test shape varies from rhombic in the inner whorls to elongate fusiform in the outer volutions. Polar ends usually blunt-pointed, more rarely rounded. Septa moderately fluted and tending to a regular pattern of folding. Chomata narrow and subquadratic in section, present in the 2-2.5 inner volutions, then becoming pseudochomata in the subsequent ones. Some darkening (supplementary deposits) appears on the base of the chambers in the innermost whorls and in the axial region of the intermediate ones. The wall in the innermost volutions consists of tectum, primatheca, and thin outer tectorium, and of tectum, diaphanotheca (thin and light) and inner tectorium (very dark and nearly as thick as the diaphanotheca); a discontinuos outer tectorium, extremely thin, might be present in places.

Remarks. Same relevant characteristics of this species (shape and size of shell, type of chomata, axial fillings) recall forms usually assigned to either Beedeina or Pseudotriticites, but the microstructure of the wall does not. Compared to particular species, it is noteworthy the overall resemblance of Pseudotritictes aff. asiaticus to the South Fergana materials originally described as Fusulina donbassica asiatica by Bensh (1972), and to the specimens from the Carnic Alps assigned to this same species by Forke \& Samankassou (2000) under the name of Beedeina (Pseudotriticites) asiaticus. Pseudotriticites aff. asiaticus from the Cantabrian Zone is similar to them in all respects except for the microstructure of the wall, since our specimens exhibit an inner tectorium clearly developed in the last volutions while tectoria are generally absent in the outer whorls of both the Bensh (1972) and Forke \& Samankassou (2000) materials; moreover, the porosity seems to be somewhat weaker than in the Central Asia and Carnic Alps species. Specimens from the Carnic Alps assigned by Davydov \& Krainer (1999) to several Beedeina species could be conspecific with Beedeina (Pseudotriticites) asiaticus described by Forke \& Samankassou (2000), as is pointed out by the last authors, and, therefore, they differ from Pseudotriticites aff. asiaticus in the same respects.

Stratigraphic data and age. Sample VA-4, VA-6, VA-8, Protriticites Zone (lowermost part), Moscovian/ Kasimovian transition interval.

\section{Pseudotriticites cantabricus Villa in Villa et al., 2015} (Fig. 7v)

Measurements. $\mathrm{L}=5.00 \mathrm{~mm} ; \mathrm{D}=1.65 \mathrm{~mm} ; \mathrm{L} / \mathrm{D}=$ $3.03 ; \mathrm{n}=5.5 ; \mathrm{d}=190 \mu \mathrm{m} ; \mathrm{D}_{\mathrm{IV}}=1.08 \mathrm{~mm} ; \mathrm{wth}=25 \mu \mathrm{m}$.

Remarks. Rhombic shape of the inner whorls, regular septal folding and four-layered and porous wall exhibiting very thin tectoria indicate that this specimen belongs to 
Pseudotriticites cantabricus, a species originally described from the Picos de Europa Formation in the Castillo del Grajal section.

Stratigraphic data and age. Sample VA-10, Protriticites Zone, lower Kasimovian (Krevyakinian).

\section{Pseudotriticites? sp.}

(Fig. 8c)

Measurements. $\mathrm{L}=9.5 \mathrm{~mm} ; \mathrm{D}=2.80 \mathrm{~mm} ; \mathrm{L} / \mathrm{D}=$ $3.39 ; \mathrm{n}=7.25 ; \mathrm{d}=130 \mu \mathrm{m} ; \mathrm{D}_{\text {IV }}=1.13 \mathrm{~mm} ; \mathrm{wth}=50 \mu \mathrm{m}$.

Remarks. Species showing in section rhombic shape of the inner whorls, moderately irregular septal folding and a three-layered and porous wall consisting of tectum, dark diaphanotheca, and very dark inner tectorium. Chomata developed on the proloculus and the one and a half innermost volution. Other supplementary deposits reduced to discontinuous fillings in the polar ends of the inner whorls.

Generic identification of this specimen is problematic since its rhombic inner shell points to Pseudotriticites, the three-layered wall points to Quasifusulinoides, and the moderately irregular septal folding is intermediate in between typical representatives of these genera.

Stratigraphic data and age. Sample CJU-1, locality situated slightly southwards the Hoyo Oscuro section, in the northern slope of La Junciana Peak. Beds probably
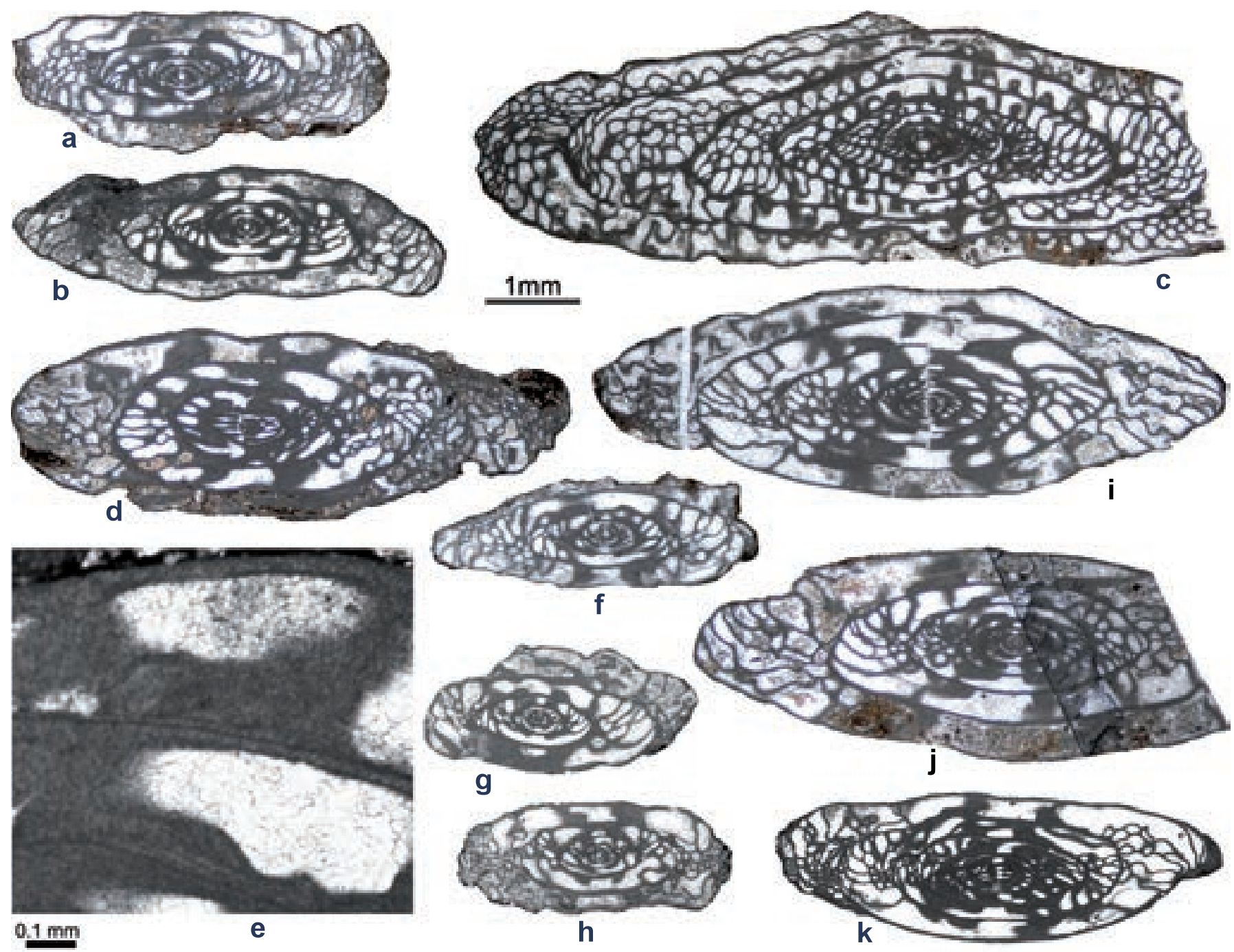

C
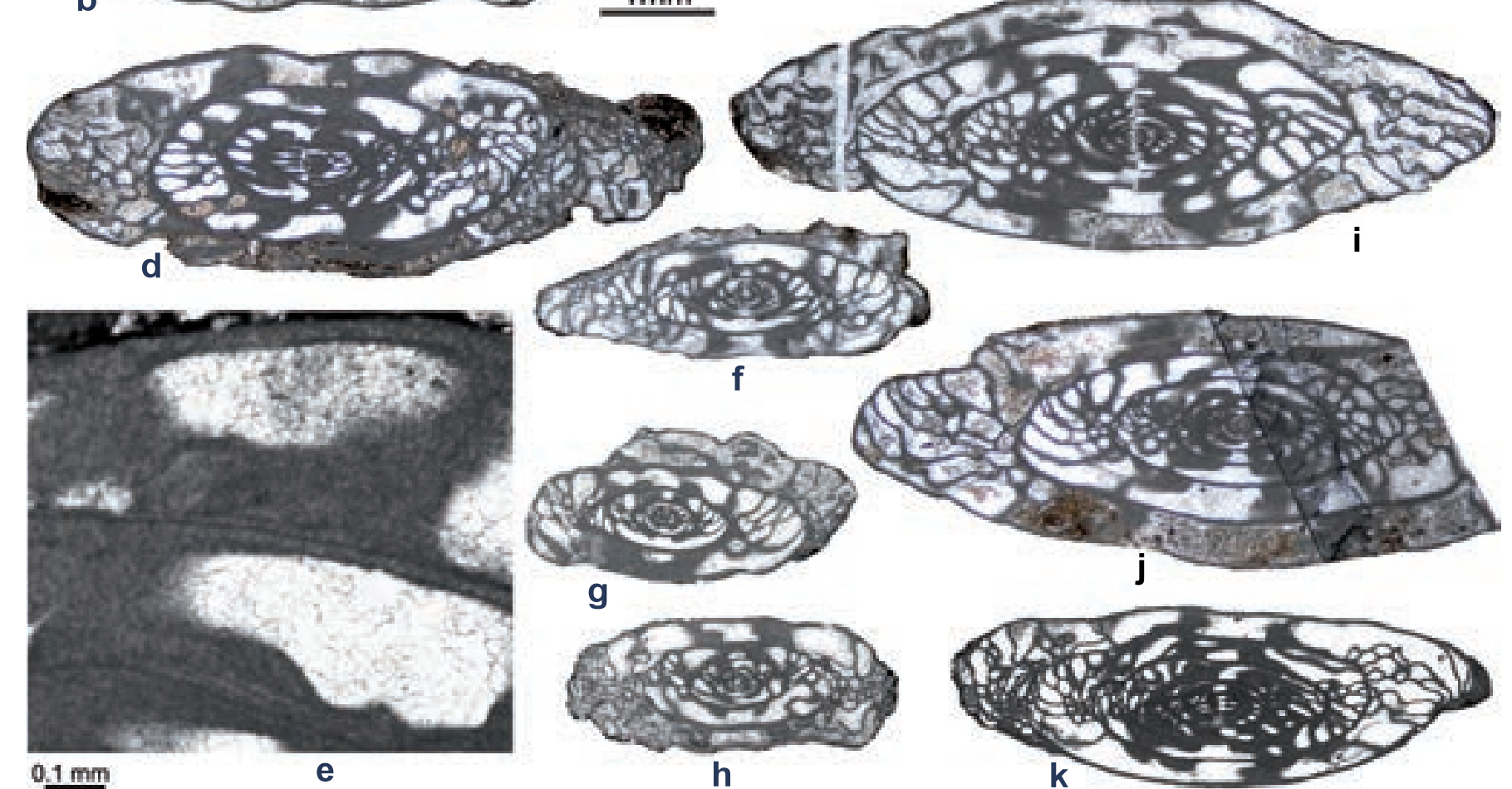

Figure 8. Fusulines of the upper part of Sequence III (uppermost ProtriticitesZone, either uppermost Krevyakinian or Krevyakinian/ Khamovnikian transition), and of Sequence IV (probably base of the Montiparus Zone, lower Khamovnikian). a-b, f-h) Protriticites cf. benshae Villa in Villa et al. (2015). (a) CJU1A/4; (b) CJU1B/1b; (f) CJU1B/2; (g) CJU1B/6; (h) CJU1B/5. c) Pseudotriticites? sp., CJU1A/3b. d-e) Montiparus? sp. (d) CJU1A/1a; (e) enlargement of the latter specimen. i-k) Protriticites? sp. (Triticites?). (i) CJU1B/8; (j) CJU1A/5a; (k) VA12/3. All specimens from La Junciana locality (Sequence III) except for VA-12 (Sequence IV) that is from Hoyo Oscuro section. 
belonging to the uppermost part of the Protriticites Zone, or the Protriticites/Montiparus transition. Kasimovian (uppermost Krevyakinian, or base of the Khamovnikian).

\section{CONCLUDING REMARKS}

1) The Hoyo Oscuro section exposes a syntectonic succession consisting of four unconformity-bounded stratigraphic sequences. They comprise both terrigenous strata with abundant carbonate clasts resembling the Áliva Formation deposits and autochthonous carbonates exhibiting microfacies similar to those of the Las Llacerias Formation.

2) Fifteen fusuline species found in the Hoyo Oscuro section are described and illustrated, among them the new species Protriticites schulzei Villa.

3) The study of the fusulines collected from this section enable us to constrain the age of the Hoyo Oscuro succession from latest Moscovian (late Myachkovian, Sequence 1) to probably early Khamovnikian (Sequence 4 ).

4) The four stratigraphic sequences are correlated with particular intervals of the Picos de Europa Formation from the Ándara Massif and the Las Llacerias section that are considered as pre-tectonic, and also with the syntectonic sequences from the northern part of Picos de Europa (Gamonedo area).

5) The inferred age of the oldest sequence (Sequence 1) of the Hoyo Oscuro section serves to establish a late Myachovian age for the onset of the Variscan deformation affecting the central and southern thrust units of the Picos de Europa imbricate system. These new data suggest that the advance of the orogenic front towards the foreland was faster than previously envisaged.

\section{ACKNOWLEDGEMENTS}

Financial support from projects FC GRUPINIDI/2018-000216 and PGC2018-099698-B-I00 is acknowledged. The authors are deeply grateful to Dr Juan Luis Alonso and Dr Holger Forke, whose critical reviews helped to improve the final manuscript.

\section{REFERENCES}

Alonso, J.L., Marcos, A. \& Suárez, A. 2009. Paleogeographic inversion resulting from large out of sequence breaching thrusts: The Leon Fault (Cantabrian Zone, NW Iberia). A new picture of the external Variscan Thrust Belt in the
Ibero-Armorican Arc. Geologica Acta, 7, 451-473; doi: 10.1344/105.000001449.

Bahamonde, J.R., Vera, C. \& Colmenero, J.R. 2000. A steepfronted Carboniferous carbonate platform: clinoformal geometry and lithofacies (Picos de Europa Region, NW Spain). Sedimentology, 47, 645-664; doi: 10.1046/j.13653091.2000.00320.x.

Bahamonde, J.R., Merino-Tomé, O.A. \& Heredia, N. 2007. Pennsylvanian microbial boundstone-dominated carbonate shelf developed in a distal foreland margin (Picos de Europa Province, NW Spain). Sedimentary Geology, 198, 167-193; doi: 10.1016/j.sedgeo.2006.12.004.

Bensh, F.R. 1969. Stratigraphy and Foraminifers of the Carboniferous Deposits of the Southwestern Otrogov and the Southern Slope of the Gissar Range. Izdatelstvo FAN Uzbekskoi SSR, Akademiya Nauk Uzbekistan, Tashkent, 174 p. (in Russian).

Bensh, F.R. 1972. Stratigraphy and Fusulinids from the Upper Palaeozoic in South Fergana. Tashkent, Izdatelstvo FAN, Akademiya Nauk Uzbekistan SSR, 146 p. (in Russian).

Colani, M. 1924. Nouvelle contribution à l'étude des fusulindés de l'Extrême-Orient. Mémoires du Service Géologique de l'Indochine, Hanoi-Haiphong, 11, 9-191.

Cózar, P., Merino-Tomé, O.A. \& Villa, E., 2007. New data (smaller foraminifera and correlation with depositional sequences) on the Las Llacerias section (Upper Pennsylvanian, Cantabrian Mountains, Spain). Facies, 53, 427-450; doi: 10.1007/s10347-007-0106-4.

Davydov, V.I. \& Krainer, K. 1999. Fusulinid assemblages and facies of the Bombaso Formation and basal Meledis Formation (Moscovian-Kasimovian) in the Central Carnic Alps (Austria/Italy). Facies, 40, 157-196; doi: 10.1007/ BF02537473.

DeCelles, P.G. \& Giles, K.A. 1996. Foreland basin systems. Basin Research, 8, 105-123; doi: 10.1046/j.13652117.1996.01491.x.

Fischer de Waldheim, G. 1829. Foraminifères d'Orbigny ou des Asiphonoïdes de Haan. Bulletin de la Société Impériale des Naturalistes de Moscou, 1, 314-333.

Forke, H. \& Samankassou, E. 2000. Biostratigraphical correlation of Late Carboniferous (Kasimovian) sections in the Carnic Alps (Austria/Italy): integrated paleontological data, facies, and discussion. Facies, 42, 177-210; doi: 10.1007/BF02562572.

Grozdilova, L.P. \& Lebedeva, N.S. 1950. Some species of Staffella from the Middle Carboniferous strata of the western slope of the Urals. Trudy Vsesoyuznogo Neftyanogo Nauchno-issledovatel'skogo Geologoeazvedochnogo Instituta (VNIGRI), 50, 5-46 (in Russian).

Julivert, M. 1978. Hercynian orogeny and Carboniferous paleogeography in NW Spain: a model of deformationsedimentation relationships. Zeitschrift der Deutschen Geologischen Gesellschaft, 129, 565-592.

Labaume, P., Mutti, E. \& Seguret, M. 1987. Megaturbidites: a depositional model from the Eocene of the SW-Pyrenean Foreland Basin. Geo-Marine Letters, 7, 91-101.

Lee, J.S. 1927. Fusulinidae of North China. Palaeontologia Sinica, ser. B., 4, 1-172. 
Maas, K., 1974. The geology of Liebana, Cantabrian Mountains, Spain. Deposition and deformation in a flysch area. Leidse Geologische Mededelingen, 49, 379-465.

Martínez-Chacón, M.L., Merino-Tomé, O.A. \& Villa, E. 2011. Brachiopod and fusulinid assemblages of Kasimovian (Pennsylvanian) age from the Ándara Massif (Picos de Europa, northern Spain). Scripta Geologica, Special Issue 7, 53-92.

Martínez García, E. \& Villa, E. 1999. Edad de los primeros signos de actividad tectónica en el Carbonífero Superior de los Picos de Europa (Asturias, NO de España). Trabajos de Geología de la Universidad de Oviedo, 21, 229-237.

Merino-Tomé, O.A., Villa, E., Bahamonde, J.R. \& Colmenero, J.R. 2006. Fusulinoidean characterization of the uppermost Moscovian-Gzhelian (upper Pennsylvanian) synorogenic depositional sequences from northern Picos de Europa Unit (Spain). Facies, 52, 521-540; doi: 10.1007/s10347006-0046-4.

Merino-Tomé, O.A., Bahamonde, J.R., Fernández, L.P. \& Colmenero, J.R. 2007. Facies architecture and cyclicity of an Upper Carboniferous carbonate ramp developed in a Variscan piggy-back basin (Cantabrian Mountains, NW Spain), In: Sedimentary Processes, Environments and Basins: a Tribute to Peter Friend (eds Nichols, G., Willians, E. \& Paola, C.). International Association of Sedimentologists, Special Publication, 38, 183-217.

Merino-Tomé, O.A., Bahamonde, J.R., Colmenero, J.R., Heredia, N., Villa, E. \& Farias, P. 2009a. Emplacement of the imbricate system of the Cuera Unit and the Picos de Europa Province in the core of the Ibero-Armorican Arc (N Spain). New precisions on the timing of the arc closure. Geological Society of America Bulletin, 112, 729-751; doi: 10.1130/B26366.1.

Merino-Tomé, O.A., Bahamonde, J.R., Samankassou, E. \& Villa, E. 2009b. The influence of terrestrial run off on marine biotic communities. An example from a thrusttop carbonate ramp (Upper Pennsylvanian foreland basin, Picos de Europa, NW Spain). Palaeogeography, Palaeoclimatology, Palaeoecology, 278, 1-23; doi: 10.1016/j.palaeo.2009.04.002.

Miklukho-Maklay, A.D., Rauzer-Chernousova, D.M. \& Rozovskaja, S.E. 1959. Order Fusulinida. In: Fundamentals of Paleontology. General Part, Protozoa (ed. Orlov, Yu.A.) Izdatel'stvo Akademii Nauk SSSR, 201-215 (in Russian).

Pasini, M. 1963. Alcuni Fusulinida del Monte Auernig (Alpi Carniche) e loro significato stratigrafico. Rivista Italiana di Paleontologia e Stratigrafia, 69, 337-382.

Pérez-Estaún, A., Bastida, F., Alonso, J.L., Marquínez, J., Aller, J., Álvarez-Marrón, J., Marcos, A. \& Pulgar, J.A. 1988. A thin-skinned tectonics model for an arcuate fold and thrust belt: The Cantabrian Zone (Variscan Ibero-Armorican Arc). Tectonics, 7, 517-537; doi: 10.1029/TC007i003p00517.

Potievskaya, P.D. 1958. Foraminifera from the Upper Bashkirian strata of the western Donetz Basin. Akademiya Nauk USSR, Trudy, Institutu Geologichnij Nauk, Seriya Stratigrafii i Paleontologii, 31, 1-73 (in Ucranian).

Putrja, F.S. 1939. Material on Upper Carboniferous stratigraphy of the eastern border of the Donets Basin. Material po
Geologii i Poleznym Iskopajemym, Azovo-chernomorskoe Geologicheskoye (Tresta) Upravlenie, Rostov n/D, 10, 97156 (in Russian).

Putrja, F.S. 1940. Foraminifera and stratigraphy of the Upper Carboniferous sediments in the eastern part of the Donets Basin. Material po Geologii i Poleznym Iskopajemym, Azovo-chernomorskoe Geologicheskoye Upravlenie, 11, 1-146 (in Russian with English summary).

Putrja, F.S. 1948. Pseudotriticitinae, a new fusulinid subfamily. Trudy L'vovskogo Geologischeskogo Obshchestva pri Gosudarstvennoom Universitete im. Ivana Franko, Ser. Paleontologia, 1, 97-101.

Rauzer-Chernousova, D.M., Gryzlova, N.D., Kireeva, G.D., Leontovich, G.E., Safonova, T.P. \& Chernova, E.I. 1951. Middle Carboniferous Fusulinids of the Russian Platform and Adjacent Regions. Akademiya Nauk SSSR, Institut Geologicheskikh Nauk, Ministerstvo Neftianoy Promyschlennosti SSSR, 229 p. (in Russian).

Remizova, S. 1992. The micropaleontological basis of the Middle/Upper Carboniferous boundary. Serija preprintov "Nauchne Dokladi", Komo Nauchni Centr Uralskoe otdelenie Rossiskaya Akademya Nauk, 295, 1-18 (in Russian).

Rjazanov, G.F. 1958. Morphology and systematics of the genus Protriticites Putrja, 1948. Dokladi Akademiya Nauk SSSR, 123, 752-755 (in Russian; translation into French of the Bureau de Recherches Géologiques et Minières no. 2117).

Rozovskaja, S.E. 1952. Fusulinids of the Upper Carboniferous and Lower Permian of the southern Urals. Trudy Paleontologicheskogo Instituta, Moskva, Akademiya Nauk SSSR, 40, 5-50 (in Russian).

Sánchez de Posada, L.C., Villa, E., Martínez Chacón, M.L., Rodríguez, R.M., Rodríguez, S. \& Coquel, R. 1999. Contenido paleontológico y edad de la sucesión de Demués (Carbonífero, Zona Cantábrica). Trabajos de Geología de la Universidad de Oviedo, 21, 339-352.

Sánchez de Posada, L.C., Villa, E., Rodríguez, R.M., Martínez Chacón, M.L., Rodríguez, S. \& Coquel, R. 2002. Paleontological content of the Demués section (Upper Carboniferous, Cantabrian Mountains, Spain) and its significance for correlation. In: Carboniferous and Permian of the World (eds Hills, L.V., Henderson, C.M. \& Bamber, E.W.). Canadian Society of Petroleum Geologists, 19, 588-595.

Schellwien, E. 1908. Monographie der Fusulinen, Teil I. Die Fusulinen des Russisch-Arktischen Meeresgebietes (nach dem Tode des Verfassers herausgegeben und Fortgesetzt von G. Dyrenfurth und H. von Staff). Paleontographica, $55,145-194$.

Sheng, J.Z. 1958. Fusulinids from the Penchi Series of the Taitzeho Valley, Lianoning. Palaeontologica Sinica, 143, 1-119.

Thompson, M.L. 1935. The fusulinid genus Staffella in America. Journal of Paleontology, 9, 111-120.

Thompson, M.L. \& Foster, C.L. 1937. Middle Permian fusulinids from Szechuan, China. Journal of Paleontology, 11, 126-144. 
Thompson, M.L. 1942. New genera of Pennsylvanian fusulinids. American Journal of Science, 240, 403-420; doi:10.2475/ajs.240.6.403.

van Ginkel, A.C. 1965. Carboniferous fusulinids from the Cantabrian Mountains. Leidse Geologische Mededelingen, 34, 1-225.

van Ginkel, A.C. \& Villa, E. 1991. Some fusulinids from the Moscovian-Kasimovian transition in the Carboniferous of the Cantabrian Mountains. Proceedings Koninklijke Nederlandse Akademie van Wetenschappen, 94, 299-359.

van Ginkel, A.C. \& Villa, E. 1999. Late fusulinellid and early schwagerinid foraminifera: relationships and occurrences in the Las Llacerias section (Moscovian/Kasimovian), Cantabrian Mountains, Spain. Journal of Foraminiferal Research, 29, 263-290.

Villa, E. 1995. Fusulináceos carboníferos del este de Asturias (N de España). Biostratigraphie du Paléozoique, 13, 261 p.

Villa, E. \& Martínez García, E. 1989. El Carbonífero superior marino de Dobros (Picos de Europa, Asturias, NW de
España). Trabajos Geología de la Universidad de Oviedo, 18, 77-93.

Villa, E. \& van Ginkel, A.C. 2000. Some late Moscovian and Kasimovian fusulinaceans from the Las Llacerias section (Cantabrian Mountains, Spain). Journal of Foraminiferal Research, 30, 219-243.

Villa, E., Merino-Tomé, O.A. \& Bahamonde, J.R., 2015. Late Moscovian to early Kasimovian fusulinids from the Ándara Massif, Picos de Europa (Pennsylvanian, Cantabrian Zone, Northern Spain). Journal of Foraminiferal Research, 45, 264-292; doi: 10.2113/gsjfr.45.3.264.

von Möller, V. 1877. Ueber Fusulinen und ähnliche Foraminiferen-Formen des russischen Kohlenkalkes. Neues Jahrbuch für Mineralogie, Geologie und Paläontologie, 1877, 139-146.

von Möller, V. 1878. Die spiral-gewundenen Foraminiferen des russischen Kohlenkalks. Mémoires de l'Academie Imperiale de Science, VII Série, 25, 1-47. 